\title{
Tracking architectural defects in university building in Malaysia
}

\author{
Haryati Mohd Isa ${ }^{1 a}$, Kharizam Ismail ${ }^{1}$, Halmi Zainol ${ }^{2}$ and Mohd Fadhli Othman ${ }^{3}$ \\ ${ }^{1}$ Dr, Quantity Surveying Department, Faculty of Architecture, Planning and Surveying, UiTM Perak Branch, Malaysia \\ ${ }^{2}$ Assoc. Prof, Dr, Town and Regional Planning, Faculty of Architecture, Planning and Surveying, UiTM Perak Branch, Malaysia \\ ${ }^{3}$ Quantity Surveying Department, Faculty of Architecture, Planning and Surveying, UiTM Perak Branch, Malaysia
}

\begin{abstract}
Building defects are always the key concern in the construction industry. Defects represent not only a loss to the project but also hamper the smooth operation of a building. Recognising the need to resolve these continuing problems, a research was mooted to track from the study of defects that occurred during the Defects Liability Period in a public university in Malaysia. This paper presents part of the research which investigates what can be learnt from the analysis of architectural defects in these projects. Two research objectives were developed (1) to investigate types of architectural defects that occurred and (2) to analyse the causes of the defects. A mixed methods approach is adopted. Data for the quantitative element of the research was drawn from defects audit records of the project. They were sorted, grouped and transferred into the SPSS software for analysis using the measure of central tendencies and frequency analysis. The findings suggest that with a proper methodology in place, defects can be effectively traced and categorised. This can provide very useful insights to their root cause and how this can be avoided in future projects.
\end{abstract}

\section{Introduction}

Defects can be associated to construction failures emanating from shortcomings during the project implementation process. In construction, parties managing construction projects are frequently aware of the signals that lead to defects or diagnose the causes of the defect to take preventive action [1] and [2]. As a result, similar defects re-appear even the building is constructed by the same contractor. This phenomenon is common in the Malaysian construction projects. Most defects in these projects are not properly recorded and tracked, which consequently lead to the client ending up rectifying the defects themselves and at their own cost [3]. Thus, this has left many clients unable to realise the full value of their investments. In contending to this problem, a research was mooted to show how defects data recorded can be re-learnt in a more systematic way to provide insights in managing future projects.

Re-learning construction defects is an emergent popular subject of research. Several studies have been conducted to investigate the types and causes of defects including the means of preventing them $[4,5,6,7,8,9,2]$. However, most of these studies tend to be limited to study only on the overall construction defects. There are limited studies that investigate defects and its relation to the work disciplines such as architectural, structural, mechanical and electrical, and the defects inherent in them. Recognising this, a research was mooted to investigate the causal relationship between the types of defects and their root cause within each work discipline involved. This is the aim to understand the nature of the defects to track their root cause. In line with this aim, three research objectives are developed: (1) investigate the types of architectural defects (2) to identify the causes of the defects and (3) to analyse the categories of the defects.

\section{Theoretical framework}

\subsection{Defects generally}

Construction defects are common phenomenon faced in the industry nowadays $[5,6,7,2]$. It occurs not only in building operational phase but also before and during the construction stage [11] and [12]. Failure to address defects would most likely contribute to additional rectification cost, hamper the smooth operation of the building and reduce its service life. In extreme cases, defects may even lead to accidents and disasters [13].

Construction defects can be defined as a failure or shortcoming in the building's function, performance, statutory or user requirements, and this may occur in its structure, fabric, services or other facilities $[6,11,12]$. Defects can be classified as patent and latent defects. Patent defects can be clearly recognized during inspection throughout the construction phase and the project's Defects Liability Period (DLP). Meanwhile,

\footnotetext{
${ }^{a}$ Corresponding author: harya966@perak.uitm.edu.my
} 
latent defects usually appear over time when the building is occupied.

Studies examining the causes of building defects were observed to take prominence since 1980s. The study on the cause and effect of defects in buildings converge to suggest that most of the defects are due to 'weaknesses' in the project implementation process. Whilst poor specifications, selection of materials, workmanship and supervision the common cited causes of defects, poor design decisions are identified as the most significant contributor to the defects. Several researchers $[5,6,13,14,7]$ stressed on the importance of designers to play their roles in eliminating defects occurrence. They should ensure that all the client requirements are well captured, translated and communicated to the other project team members throughout the project implementation process supported with proper documentation system [15]. In addition, [16] added that the problem with defects is not so much a matter of not knowing what to do but applying correctly what is known.

\subsection{Defects and its implication in the Malaysian construction industry}

One of the most important 'disease' that affect the overall performance of construction industry in Malaysia is construction defects $[17,18,19]$. These defects have caused the government an enormous sum of money. The Malaysian government has continually provided allocations for maintenance works for completed buildings and a significant proportion are for defects rectification work [12]. Owing to the seriousness of these problems, the government is considering implementing punitive measures against those who flout the rules and regulations.

As an added initiative to minimize construction defects in public projects, the Public Work Department (PWD) had undertook several proactive actions such as:

a) forming Building Facility Maintenance Division to monitor and audit Malaysian public buildings

b) organising an internal workshop to discuss on issues promoting defects during project stages. The common causes of the defects highlighted are: (1) lack of monitoring or supervision by responsible authorities, (2) lack of technical expertise and full reliance on contractors or consultants, (3) lack of coordination between agencies involved, (4) internal problems faced by the contractors, and (5) contractual issues. Notwithstanding, the government have realised that this cannot continue and they are not getting the value for money for their projects

c) recording and publishing several construction defects that occurred in public buildings and their lessonlearnt in a book

d) enforcing Defects Liability Management System for the management of defective works on seven hospital projects constructed in the Malaysian Eight Plan (RMK8)

Following this, [20] found that defects are being repeated in many projects even when constructed by the same contractor. Thus, a study on the nature of the defects and possible approaches to track their root cause is very necessary. The question of what are the defects, why they are recurring and what are the root causes are raised.

\subsection{Rationale for tracking construction defects}

By systematically recording and tracking defects, the types, causes and categories of each defect can be identified. Besides this, the recurring defects can also be traced. These significant data can be used to provide LL to assist the project team in identifying what went wrong and how to better manage future projects $[21,22,23]$. As a result, they could improve its cost efficiency and increase their design and performance quality [23] and [2].

\section{Research methodology}

A single case study of a Malaysian public university is chosen. A combination of qualitative and quantitative methods was adopted. Data for the quantitative element of the research was drawn from audit records of defects identified during the projects DLP. They were sorted, grouped and transferred into the SPSS software for analysis using the measure of central tendency and frequency analysis.

The qualitative research method was adopted to examine the types and causes of the defect. This was carried out by critically analyzing project audit documents. For the purpose of tracking the root cause of the defects, data on the defects were categorized into design, workmanship, material, lack of protection, vandalism, nature, maintenance and mishandling defects.

\section{Findings}

The defects data were analysed and summarized in Table 1 to Table 5. Five major defective elements were identified and documented in this project.

\subsection{Overall number and percentage of defects}

Table 1 highlights the overall number and percentage of defects according to their work disciplines. There are four work disciplines involved namely architectural, civil, mechanical and electrical.

Table 1. Overall number and percentage of defects.

\begin{tabular}{|c|c|c|}
\hline Work discipline & $\begin{array}{c}\text { Number of } \\
\text { defects }\end{array}$ & $\begin{array}{c}\text { Percentage of } \\
\text { defects (\%) }\end{array}$ \\
\hline Architectural & 1175 & 63 \\
\hline Mechanical & 364 & 19 \\
\hline Electrical & 275 & 15 \\
\hline Civil & 60 & 3 \\
\hline Total & 1874 & 100 \\
\hline
\end{tabular}


A total of 1874 defects were recorded in the university. Architectural defects recorded as the most defective work discipline followed by mechanical, electrical and civil defects.

\subsection{Distribution of architectural defects by element and block}

Table 2 indicates the number of architectural defects based on the elements for the five identified blocks. College was observed to record the highest number of architectural defects, followed by Faculty, Library, Administration Building and Student Centre respectively.

Table 2. Overall number of architectural defects by element/block.

\begin{tabular}{|c|c|c|c|c|c|c|c|}
\hline \multirow{2}{*}{ Element } & \multicolumn{5}{|c|}{ Block } & \multirow{2}{*}{ 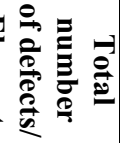 } & \multirow{2}{*}{$\prod_{0}^{\infty}$} \\
\hline & $\mathbf{A}$ & B & $\mathbf{C}$ & D & $\mathbf{E}$ & & \\
\hline $\begin{array}{|ll|}\text { 1. Wall, } & \begin{array}{l}\text { Floor } \\
\text { and }\end{array} \\
& \text { Finishes } \\
\end{array}$ & 94 & 127 & 69 & 59 & 8 & 357 & 1 \\
\hline $\begin{array}{l}\text { 2. Window } \\
\text { and } \\
\text { Fittings }\end{array}$ & 155 & 39 & 20 & 21 & 7 & 242 & 2 \\
\hline \begin{tabular}{|ll}
3. & Doors \\
and \\
Fittings
\end{tabular} & 60 & 69 & 48 & 38 & 2 & 217 & 3 \\
\hline $\begin{array}{ll}\text { 4. } & \text { Ceiling } \\
& \text { Finishes }\end{array}$ & 45 & 122 & 10 & 10 & 1 & 188 & 4 \\
\hline \begin{tabular}{|l} 
5. Sanitary \\
Fittings, \\
Fixtures \\
and \\
Toilet \\
Cubicles
\end{tabular} & 78 & 39 & 5 & 5 & 8 & 135 & 5 \\
\hline 6. Staircase & 5 & 12 & 2 & 1 & 0 & 20 & 6 \\
\hline 7. Roof & 5 & 6 & 0 & 0 & 0 & 11 & 7 \\
\hline $\begin{array}{ll}\text { 8. } & \text { Building } \\
\text { Signage }\end{array}$ & 1 & 0 & 1 & 1 & 0 & 3 & 8 \\
\hline \begin{tabular}{|ll} 
9. & Other \\
& Architec \\
tural
\end{tabular} & 2 & 0 & 0 & 0 & 0 & 2 & 9 \\
\hline $\begin{array}{l}\text { Total } \\
\text { number of } \\
\text { defects/ } \\
\text { block } \\
\end{array}$ & 445 & 414 & 155 & 135 & 26 & 1175 & \\
\hline Rank & 1 & 2 & 3 & 4 & 5 & & \\
\hline
\end{tabular}

A- College, B- Faculty, C- Library, D- Administration Building, F- Student Centre

Nine elements were involved in architectural works. The top five most defective elements are; (1) Wall, Floor and Finishes (2) Windows and Fittings (3) Doors and Fittings (4) Ceiling Finishes and (5) Sanitary Fittings, Fixtures and Toilet Cubicles. Meanwhile, Others Architectural is identified as the least defective element and only revealed in College.

\subsection{Summary of major architectural defects}

Table 3 to Table 7 recapitulates the types, causes and categories of architectural defects for five major elements. In addition, the table also highlights the frequent types, causes and categories of architectural defects that occurred in the building.

\subsubsection{Types of architectural defects}

The types and most frequent type of architectural defects that occurs are as follows:

Table 3. Types and frequent type of architectural defects.

\begin{tabular}{|c|c|}
\hline Type of defects & $\begin{array}{c}\text { Frequent type of } \\
\text { defects }\end{array}$ \\
\hline $\begin{array}{ll}\text { A) } & \text { Wall, Floor and Finishes } \\
\text { 1. } & \text { Water seepage } \\
\text { 2. } & \text { Dirty floor } \\
\text { 3. Unevenness paint } \\
\text { 4. Untidy wall painting } \\
\text { 5. Peeling of paint } \\
\text { 6. Plaster crack } \\
\text { 7. Wall damaged } \\
\text { 8. Uneven floor level } \\
\text { 9. Detached of floor tiles } \\
\text { 10. Floor tile crack } \\
\text { 11. Pebble wash not provided } \\
\text { 12. Fungus } \\
\text { 13. Improper fixing of wall tile } \\
\text { 14. Partition not provided } \\
\text { 15. Detached of skirting }\end{array}$ & \multirow{6}{*}{$\begin{array}{l}\text { 1. Non-functional } \\
\text { windows } \\
\text { 2. Water seepage } \\
\text { 3. Door damaged } \\
\text { 4. Window } \\
\text { damaged } \\
\text { 5. Untidy wall } \\
\text { painting }\end{array}$} \\
\hline B) Windows and Fittings & \\
\hline $\begin{array}{l}\text { 1. Non-functional window } \\
\text { 2. Window damaged } \\
\text { 3. Dirty window } \\
\text { 4. Window ironmongery } \\
\text { damaged } \\
\text { 5. Incomplete installation of } \\
\text { window } \\
\text { 6. Blind not provided } \\
\text { 7. Window corrode }\end{array}$ & \\
\hline C) Doors and Fittings & \\
\hline $\begin{array}{ll}\text { 1. } & \text { Door damaged } \\
\text { 2. } & \text { Ironmongery damaged } \\
\text { 3. } & \text { Incomplete installation of } \\
\text { ironmongery } \\
\text { 4. Door key not provided } \\
\text { 5. Untidy door painting } \\
\text { 6. Non-functional door } \\
\text { 7. Detached of door stopper } \\
\text { 8. Peeling of paint at door } \\
\text { 9. Door knob inverted } \\
\text { 10. Door frame damaged }\end{array}$ & \\
\hline $\begin{array}{ll}\text { D) } & \text { Ceiling Finishes } \\
\text { 1. } & \text { Ceiling perforated } \\
\text { 2. } & \text { Ceiling not provided } \\
\text { 3. } & \text { Leakage } \\
\text { 4. } & \text { Ceiling damaged } \\
\text { 5. } & \text { Fungus } \\
\text { 6. } & \text { Stain mark } \\
\end{array}$ & \\
\hline
\end{tabular}




\begin{tabular}{|ll|}
\hline E) & $\begin{array}{l}\text { Sanitary Fittings, Fixtures and } \\
\text { Toilet Cubicles }\end{array}$ \\
\hline 1. & Incomplete installation of \\
& fittings \\
2. & Tap not provided \\
3. & Leakage \\
4. & Blockage \\
5. & Detached of sanitary fittings \\
6. & Non-functional floor trap \\
7. & Water closet cover damaged \\
8. & Improper installation of fittings \\
9. & Cistern overflow \\
10. & Flush damaged \\
\hline
\end{tabular}

Note: The element, type of elemental defects and frequent defective items are all in ranking order

The major architectural defects are identified and summarised as follows:

a) Wall, Floor and Finishes are the major defective elements with the most type of defects aroused. With 15 types of defects that occurred, water seepage recorded the most defects and detached of floor skirting recorded least

b) Window and Fittings are identified as the second most defective element. A number of seven defects were observed with non-functional window highlighted as the most defective works. Meanwhile, window corrode as the least defective element

c) Doors and Fittings are the third most defective element with door damaged as the most defective works. The least defective works in this element is door frame damaged

d) Perforated ceiling is the most defective works in Ceiling and Finishes while uneven ceiling is the least defective work in this element

e) The least defective element is Sanitary Fittings, Fixtures and Toilet Cubicles. Incomplete installation of fittings are the most defective works while overflow cistern and flush damaged recorded least

The table also highlights five most frequent defective items. Non-functional windows appears as the most defective items followed by water seepage, door damaged, window damaged and untidy painting to wall.

\subsubsection{Causes of architectural defects}

Table 4 indicates the causes and frequent causes of defects for each element involved. The results are as follows:

Table 4. Causes of architectural defects.

\begin{tabular}{|c|c|c|}
\hline Element & Causes of defects & $\begin{array}{l}\text { Frequent causes } \\
\text { of defects }\end{array}$ \\
\hline $\begin{array}{l}\text { Wall, } \\
\text { Floor and } \\
\text { Finishes }\end{array}$ & $\begin{array}{l}\text { 1. Lack of protection } \\
\text { 2. Poor workmanship } \\
\text { 3. Work in accordance to } \\
\text { specification } \\
\text { 4. Incorrect levelling } \\
\text { 5. Work in accordance to } \\
\text { specification } \\
\text { 6. Exposed to weather }\end{array}$ & \\
\hline
\end{tabular}

\begin{tabular}{|c|c|c|}
\hline & $\begin{array}{l}\text { 7. Vandalism } \\
\text { 8. Poor quality of } \\
\text { material } \\
\text { 9. Mishandling by users } \\
\text { 10. Design default } \\
\text { 11. Construction debris } \\
\text { blockage }\end{array}$ & \\
\hline $\begin{array}{l}\text { Windows } \\
\text { and } \\
\text { Fittings }\end{array}$ & $\begin{array}{l}\text { 1. Poor workmanship } \\
\text { 2. Work in accordance to } \\
\text { specification } \\
\text { 3. Vandalism } \\
\text { 4. Lack of protection } \\
\text { 5. Poor quality of } \\
\text { material } \\
\text { 6. Mishandling by users } \\
\text { 7. Exposed to weather } \\
\text { 8. Heavy thing crashed }\end{array}$ & $\begin{array}{l}\text { 1. Work in } \\
\text { accordance } \\
\text { to } \\
\text { specification }\end{array}$ \\
\hline $\begin{array}{l}\text { Doors and } \\
\text { Fittings }\end{array}$ & $\begin{array}{l}\text { 1. Work in accordance to } \\
\text { specification } \\
\text { 2. Vandalism } \\
\text { 3. Mishandling by users } \\
\text { 4. Poor workmanship } \\
\text { 5. Poor quality of } \\
\text { material } \\
\text { 6. Exposed to weather } \\
\text { 7. Lack of protection } \\
\text { 8. Design default }\end{array}$ & $\begin{array}{l}\text { 2. Poor } \\
\text { workmanship } \\
\text { 3. Lack of } \\
\text { protection } \\
\text { 4. Vandalism } \\
\text { 5. Water } \\
\text { seepage }\end{array}$ \\
\hline $\begin{array}{l}\text { Ceiling } \\
\text { Finishes }\end{array}$ & $\begin{array}{l}\text { 1. Work in accordance to } \\
\text { specification } \\
\text { 2. Lack of protection } \\
\text { 3. Poor workmanship } \\
\text { 4. Incorrect levelling } \\
\text { 5. Vandalism } \\
\text { 6. Mishandling by users }\end{array}$ & \\
\hline $\begin{array}{l}\text { Sanitary } \\
\text { Fittings, } \\
\text { Fixtures } \\
\text { and Toilet } \\
\text { Cubicles }\end{array}$ & $\begin{array}{l}\text { 1. Poor workmanship } \\
\text { 2. Lack of protection } \\
\text { 3. Construction debris } \\
\text { blockage } \\
\text { 4. Mishandling by users } \\
\text { 5. Vandalism } \\
\text { 6. Exposed to weather } \\
\text { 7. Poor quality of } \\
\text { material } \\
\text { 8. Work not accordance } \\
\text { to plan and layout } \\
\text { 9. Valve gate off } \\
\end{array}$ & \\
\hline
\end{tabular}

Note: The element, causes of elemental defects and frequent causes of defects are all in ranking order

a) There are 12 causes of defects appeared in Wall, Floor and Finishes. Lack of protection is the major causes of defects in this element, while construction debris blockage is the least

b) Poor workmanship is the main causes of defects in Windows and Fittings and Sanitary Fittings, Fixtures and Toilet Cubicles. Heavy thing crashed is the least defective causes in Windows and Fittings. Meanwhile, valve gate off is the least in Sanitary Fittings, Fixtures and Toilet Cubicles

c) Doors and Fittings and Ceiling Finishes have similar number and major causes of defects i.e work in accordance to specification. Design default and 
mishandling by users are the two least causes of defects in these elements

Five most frequent causes of defects were found such as work in accordance to specification, poor workmanship, lack of protection, vandalism and water seepage.

\subsubsection{Categories of architectural defects}

Table 5 indicates that there are eight categories of defects involved in architectural works.

Table 5. Categories of architectural defects.

\begin{tabular}{|c|c|c|c|c|c|c|c|c|c|}
\hline \multirow{2}{*}{ 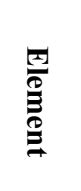 } & \multicolumn{9}{|c|}{ Categories of defects } \\
\hline & $\mathbf{W}$ & LOP & $\mathbf{V}$ & Mt & $\begin{array}{c}\mathbf{M} \\
\mathbf{h}\end{array}$ & $\mathbf{M}$ & $\mathbf{N}$ & D & 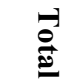 \\
\hline WFF & 167 & 119 & 58 & 9 & 11 & 5 & 10 & 2 & 381 \\
\hline WF & 134 & 24 & 39 & 0 & 9 & 17 & 6 & 0 & 229 \\
\hline $\mathrm{DF}$ & 96 & 2 & 58 & 0 & 36 & 12 & 7 & 2 & 213 \\
\hline $\mathrm{CF}$ & 59 & 28 & 8 & 91 & 1 & 0 & 0 & 0 & 187 \\
\hline $\mathrm{SF}$ & 110 & 3 & 6 & 29 & 8 & 1 & 5 & 0 & 162 \\
\hline Total & 566 & 176 & 169 & 129 & 65 & 35 & 28 & 4 & \\
\hline Rank & 1 & 2 & 3 & 4 & 5 & 6 & 7 & 8 & \\
\hline
\end{tabular}

WFF - Wall, Floor and Finishes, WF- Window and Fottings, DFDoors and Fittings. CF- Ceiling Finishes, SF- Sanitary Fttings, Fixtures and Toilet Cubcles

Workmanship (W) is the main categories of defects followed by lack of protection (LOP), vandalism (V), maintenance $(\mathrm{Mt})$, mishandling by users $(\mathrm{Mh})$, material (M) and nature $(\mathrm{N})$. Defects due to design (D) defaults are the least categories occurred in this work discipline. The frequency of the categories of defects that occurred in each element as follows:

a) Wall, Floor and Finishes - workmanship is the most frequent categories of defects, while design is the least

b) Windows and Fittings - workmanship is the most frequent categories of defects, while nature is the least. There is no defects occurred due to design and maintenance

c) Doors and Fittings - workmanship is the most frequent categories of defects. Design and lack of protection are two least categories that appeared in this element. None defects occurred due to maintenance fault

d) Ceiling Finishes - Maintenance is the major categories of defects and mishandling by users is the least category. None defects are due to design, material and nature

e) Sanitary Fittings, Fixtures and Toilet Cubicles workmanship is the most frequent categories of defects, while material is the least. There is no design defects found in this element

\section{Discussions}

The problem of many architectural defects is continuing and tends to be repeated in many projects. Majority of the defects causes is due to workmanship as a result of poor quality of work, lack of supervision and installation or protection method during the construction stage. This is further supported by the statement from [21] and [17]. Design defects are due to poor design planning and poor material selection during the design stage.

Material defects are mostly due to inappropriate materials applied to the functional of the buildings as mentioned by [7]. It is found that material defects usually took time to develop until the occupancy stage. In addition, more maintenance defects were expected as the buildings aged. Meanwhile, vandalism defects are believed to be influenced by attitude and background of the population surrounding the buildings.

These defects are underpinned by the adequacy and effectiveness of the management process practiced in design and building process of the hospitals. There were obvious issues surrounding the design of some components of the building, selection of materials, workmanship and supervision. While generally the final quality and standards of the university was deemed acceptable to the EU, in some key areas these elements needs to be further clarified. Elements like ambiguity in the process of determining specifications should be eliminated. Indeed, these should be well captured and maintained by the professionals including the end user (EU) during the early stage of the project. Better coordination and co-operation amongst the design team, EU and the contractor throughout the project implementation is also an important factor that needs to be considered. This is in line with [24].

Recording defects and classifying them into systematic categories are useful for identifying the type of defect; which defect is most probably caused by what; and what defects are most recurring. These are significant data which can be used to learn to assist identify what went wrong. Majority of the defects are often interrelated. However, this requires the project teams to open their mind and embrace the continuous learning culture. They need to see the system as a positive and systematic approach that can encourage a better co-ordination and co-operation amongst the project team towards achieving zero defects in future projects.

\section{Conclusions}

Findings from this research underline the significance of re-learning construction defects. The audit provides a platform for a post-mortem study to learn weaknesses in the project implementation process for future improvement.

The study of defects identified during the DLP can be very significant as a control mechanism to ascertain the validity and reliability of a project's implementation process. Without this study there is little that can be achieved to assess whether the project management team 
has achieved economy, efficiency and effectiveness in their project management process.

While much can be drawn from the existing study, much more can be can be learnt if the defects data can be exploited using more advanced statistical tools. Further investigations to study the "ripple-effect" of the causal relationships of the process that led to the defects to better track the root cause of the defects is considered for the next stage of the study.

\section{Acknowledgement}

The authors would like to thank the University A and the Building Audit Facilities team for their contribution in the research project and the provision of vital information. Comments of the anonymous reviewers who were very helpful are gratefully acknowledged.

\section{References}

1. Jorgensen, K. (2009). Failures and defects in the building process - applying the bow-tie approach. CIB Joint International Symposium, Dubrovnik, Croatia

2. Haryati M.I, Hassan, F., Takim,R., Che Mat, M., and Ithnin, Z. (2010). How adequate is adequate? a case of the adequacy in determining client requirements in the construction of four public hospitals in Malaysia. CIB World Congress, Salford University

3. Haryati, M.I. (2014). An improved operational framework for defects liability management system for design and build public hospital projects, University Technology MARA Malaysia. Unpublished $\mathrm{PhD}$ Thesis (PhD)

4. Atkinson, A. (1998). Human error in the management of building projects. Construction, Management and Economics, 16(3), 339-349

5. Josephson, P.E., and Hammarlund, Y. (1999). The causes and costs of defects in construction: a study of seven building projects. Automation in Construction, 8(6), 681-687

6. Pheng, L.S., and Wee, D. (2001). Improving maintenance and reducing building defects through ISO 9000. Journal of Quality in Maintenance Engineering, 7(1), 6-24

7. Chong, W.K., and Low, S.P. (2005). Assessment of defects at construction and occupancy stages. Journal of Performance of Constructed Facilities, 19(4), 283-289

8. Sommerville, J. (2007). Defects and rework in new build: an analysis of the phenomenon and drivers. Structural Survey, 26(8), 391-407

9. Zietsman, R. (2008). Defects in the construction industry - then and now. $5^{\text {th }}$ Postgraduate Conference on Construction Industry Development, Bloemfontein, South Africa

10. Mills, A., Love, P.E.D., and Williams, P. (2009). Defect costs in residential construction. Journal of Construction Engineering and Management, 135(1), $12-16$
11. Lateef, O.A., Mohd Faris, K., and Arazi,I. (2010). Sustainability in the context of maintenance: building defects in the Malaysian university campuses. Journal of Retails and Leisure Property, 9(2), 137-149

12. Kian, P.S. (2001). A review of factors affecting building defects in Singapore. Dimensi Teknik Sipil, 3(2), 64-68

13. Grobler, K., and Pretorius, L. (2002). An evaluation of design-build as procurement method for building an civil engineering projects in South Africa. Journal of South African Institution of Civil Engineering, 44(1), 13-19

14. Andi, and Minato, T. (2004). Representing causal mechanism of defective designs: a system approach considering human errors. Construction Management and Economics, 21(3), 297-305

15. Atkinson, A.R. (2002). The pathology of building defects; a human error approach. Engineering Construction and Architectural Management, 9(1), 53-61

16. Ibrahim, A.R., Roy, M.H., Ahmed, Z., and Imtiaz, G. (2010). An investigation of the status of the Malaysian construction industry. Benchmarking An International Journal, 17(2), 294-308

17. Ahzahar, N., Karim, N.A., Hassan, S.H. and Eman, J. (2011). A study of contribution factors to building failures and defects in construction industry. Procedia Engineering, 20(3), 249-255

18. Palaniandy, P.R. (2011). A study on factors affecting quality deterioration in hausing construction industry in Klang Valley, Open University Malaysia. Unpublished MSc Thesis (MSc)

19. Hassan, F., Haryati M.I., Che Mat, M., Ithnin, Z., and Sapisey, Z. (2009). Report on defects during defects liability period for public hospital projects in Malaysia. Kuala Lumpur

20. Wardhana, K., and Hardipriono, C. (2003). Study of the recent building failures in the United States. Journal of Performance of Construction and Facilities, 17(3), 157-158

21. Ilozor, B.D., Okoroh, M.I. and Egbu, C.E. (2004). Understanding residential house defects in Australia from the State of Victoria. Building and Environment, 39(3), 327-337

22. Carrillo, P. (2006). Lessons learned practices in the engineering, procurement and construction sector. Engineering, Construction and Architectural Management, 12(3), 236-250

23. Le, M.A.T., and Bronn, C. (2007). Linking experience and learning: application to multiproject building environments. Engineering, Construction and Architectural Management, 14(2), 150-163

24. Dvir, D., Raz, T., and Shenhar, A. (2003). An empirical analysis of the relationship between project planning and project success. International Journal of Project Management, 21(2), 89-95 